\title{
Kod Etika Kewartawanan Malaysia DAN KEPENTINGANNYA KEPADA Profesionalisme Wartawan Akhbar Berbahasa Melayu di Malaysia
}

\author{
Nor Zaliza Sarmiti \\ Universiti Malaya, Malaysia \\ zaliza_s@um.edu.my \\ Hamedi Mohd Adnan \\ Universiti Malaya, Malaysia \\ hamedi@um.edu.my
}

\section{ABSTRACT \\ MALAYSIAN JOURNALISM CODE OF ETHICS AND ITS IMPORTANCE TO THE PROFESSIONALISM JOURNALIST OF MALAY NEWSPAPER IN MALAYSIA}

\begin{abstract}
Malaysian Journalism Code of Ethics was introduced in 1989 by Malaysian Press Institute (now known as MPI) and the Newspaper Editors' Association (ONE) has paves the way for the rising of professionalism in national journalism. According to Djohn E. Drewry, there is a need to form an ethic to elevate a career into a professional. Furthermore, with the advancement of media technology and communication, it threatens the careers of journalists and requires into the debates or re-evaluation done on this topic, more so now when journalism work are easily regulated by the public. Do journalists use the existing code of ethics and what is its importance to the professionalism of a journalist's career? This question needs to be answered by journalists as the use of this code of ethics is still less even though the importance is recognized by many scholars. This study utilises the quantitative approach, whereby 272 journalists from five Malay language newspaper were asked to answer a questionnaire. The questionnaires were distributed randomly and analyzed descriptively. This study found that the majority of journalists knew about the Code of Ethics (EKM) and its importance in elevating the professionalism of journalism in Malaysia. Findings from the study also found that journalists possess a high level of ethics according on the practice of the eight EKM.
\end{abstract}

Keywords: Code of ethics, professionalism, journalists, Malay newspapers, Malaysia

\section{PENGENALAN}

Malaysia merupakan sebuah negara sedang membangun yang kini dalam usaha menggerakkan rakyat serta negara ke arah mencapai status negara maju. Dalam usaha mencapai sasarannya, 
media yang dilihat sebagai estet keempat dalam doktrin kekuasaan bersama-sama eksekutif, legislatif, judisial perlu berganding dengan pemerintah menjayakan agenda pembangunan yang dirancang. Seperti yang dinyatakan oleh Wong (2004), media berhubung baik dengan kerajaan dan memainkan peranan yang penting untuk membantu pemerintah serta turut sama dalam agenda pembangunan negara. Ogan (1982) dalam New International Information Order telah menunjukkan wujudnya gaya yang berbeza antara media Barat yang wartawannya menganjurkan polisi laissez-faire dalam mengumpul dan menyebarkan maklumat dengan Negara Dunia Kedua dan Ketiga, yang wartawannya sering merasakan penting untuk menerima input dari kerajaan dalam pelaporan berita.

Di Malaysia, peranan media, terutamanya akhbar yang memegang tradisi kuasa pemberitaan seawal abad ke-19, amat penting dalam masyarakat. Akhbar berperanan bukan sahaja sebagai medium saluran maklumat tetapi turut berperanan dalam mendidik, mempengaruhi, menghibur dan bertindak sebagai agen perubahan yang berupaya menggerakkan masyarakat ke arah sebuah negara yang harmoni dan maju. Akhbar berperanan menyampaikan maklumat atau berita dengan tahap kredibiliti yang tinggi, dipercayai, dan lengkap (Schweiger, 2000; Flanagin \& Metzger, 2000; McQuail, 2005; Jarvis, Stroud \& Gilliland, 2009) kepada masyarakat. Namun, ini tidak bererti dunia pemberitaan berjalan dengan lancar tanpa wujudnya konflik. Isu berkaitan hubungan media dengan kerajaan yang memerintah, akhbar sebagai sektor industri, pemilikan serta pemusatan media, penglibatan serta campur tangan luar dan peribadi, perkembangan teknologi dunia kewartawanan dan pemberitaan, sentiasa melingkari dunia kewartawanan dan menjadi penyebab wartawan seringkali dipandang serong oleh masyarakat. Ini menyebabkan dilema dalam kerjaya wartawan selain mencabar profesionalisme kerjaya.

Shoemaker dan Reese (2004) menyatakan bahawa kandungan media dipengaruhi oleh perlakuan dan orientasi peribadi pekerja media, profesionalisme, polisi korporat, bentuk pemilikan, persekitaran ekonomi, pengiklan, khalayak, ideologi dan yang paling penting iaitu kerajaan. Konflik serta tekanan yang muncul dalam persekitaran dunia kewartawanan nyata akan mencorakkan kandungan media sebagaimana disebut oleh McQuail (2010: 244) bahawa wartawan bekerja dalam lingkungan sekatan dan pengaruh, serta struktur yang memberi kesan kepada output pemberitaan. Wartawan menjalankan tugas dan membuat setiap keputusan dalam kerjaya ditengah-tengah kuasa dan pengaruh yang ada. Bukan mudah bagi wartawan untuk bebas melaporkan berita dengan menolak ke tepi kehendak kuasakuasa di persekitarannya dan dalam masa yang sama mempertahankan profesionalisme kewartawanan. Di sinilah peranan kod etika diperlukan bagi memberikan garis panduan kepada para wartawan untuk terus kekal dengan nilai-nilai yang dibentuk sebagai satu mekanisme piawaian tingkah laku seragam dalam berdepan cabaran kerjaya.

Terkini, kerjaya wartawan semakin dicabar apabila perkembangan teknologi digital media dan komunikasi memberikan satu lagi bentuk tekanan baru. Pengaruh kewartawanan warga yang semakin kuat ditambah dengan kaedah baharu pelaporan berita secara langsung dalam era digital maklumat benar-benar mencabar profesionalisme wartawan. Mortensen dan Keshelashvili (2013) menyebut bahawa kewartawanan warga dianggap menyumbang kepada ancaman kerjaya wartawan profesional. Kegiatan kewartawanan pada era digital kelihatan semakin hari semakin banyak dijelajahi oleh golongan bukan profesional yang tidak mempunyai ilmu dan latihan khusus kewartawanan. Selain itu, mereka bebas berkongsi bahan serta maklumat, terutama dari dalam talian yang diperoleh dengan cepat dan lebih bebas tanpa terikat dengan dasar serta proses kerja editorial sebagaimana yang dilakukan 
oleh wartawan profesional. Pendigitalan media telah mengubah dunia kewartawanan dan pemberitaan dari segi amalan, rutin kewartawanan, serta model perniagaan yang secara langsung mempengaruhi ideologi, sistem nilai dan identiti wartawan (Craft, 2017; Wasserman, 2020). Maka, timbul kembali kebimbangan tentang kemungkinan berlakunya penurunan piawaian dan kewibawaan pelaporan serta penulisan berita oleh wartawan. Hal ini memerlukan usaha para sarjana untuk meneliti semula sejauh mana instrumen kawalan kualiti seperti kod etika berguna dalam mendepani cabaran baru dunia pemberitaan.

\section{KOD ETIKA KEWARTAWANAN DAN KEPENTINGANNYA KEPADA PROFESIONALISME KEWARTAWANAN}

Etika merupakan salah satu cabang falsafah yang dikaitkan dengan komponen moral dalam kehidupan manusia. Umumnya, ini berkait dengan perlakuan yang benar dan yang salah. Namun dalam memberikan makna sebenar, ini tidak mudah kerana sudut dan pandangan masyarakat berbeza-beza seperti yang dinyatakan oleh Halimahton (2004), sesuatu yang beretika pada kaca mata seseorang berkemungkinan tidak dianggap beretika oleh orang. Ini kerana makna etika itu sangat subjektif dan bergantung pada sosial serta budaya pada masa tertentu. Selain itu, isu betul dan baik bergantung pada sistem kepercayaan seseorang individu yang lazimnya terhasil daripada percantuman pelbagai unsur dan nilai dalam kehidupan seperti nilai budaya dan agama. Pembentukan sebuah etika dalam kerjaya mampu menyediakan satu garis panduan yang ideal untuk para pengamal sesuatu bidang untuk melaksanakan tugas dan tanggungjawab dengan penuh amanah serta berwibawa tetapi, maknanya mungkin berbeza bergantung pada sistem, persekitaran media serta kepercayaan pengamalnya.

Kod etika kewartawanan adalah satu bentuk garis panduan yang berguna dalam menuntun wartawan melaksanakan tugas secara profesional. McQuail (1992) menyatakan kod etika kewartawanan merujuk kepada suatu set prinsip profesionalisme yang diperoleh dan dikawal sendiri oleh wartawan. Wartawan akan mempunyai satu tingkat personaliti dan nilai kerja yang baik sekiranya kod etika kewartawanan yang diwujudkan menjadi asas atau prinsip dalam melaksanakan pekerjaannya. Dan hal ini, menjadi nilai tambah kepada keupayaan menaikkan profesionalisme kewartawanan.

Jay Black et al (1998) menyatakan bahawa kod etika kewartawanan dapat membantu wartawan mengenal pasti banyak masalah dan menyedarkan wartawan bahawa mereka bertanggungjawab dalam mencari dan melaporkan berita dengan lengkap dan tepat, dan juga mengingatkan wartawan supaya sentiasa berwaspada terhadap tekanan yang akhirnya melenyapkan kebebasan akhbar. Kepentingan mewujudkan satu garis panduan kerjaya sebagai rangka rujuk dalam melaksanakan tugasan mampu memandu wartawan untuk bergerak secara positif dan mengelakkan diri dipengaruhi oleh persekitaran yang menggugat peranan dan tanggungjawab mereka. Amalan serta pematuhan kepada kod etika kewartawanan akan mengelakkan wartawan daripada dimanipulasi dan memanipulasi kandungan pemberitaan yang dilakukan (Filak, 2019).

Bagi kod etika kewartawanan di Malaysia, perkara yang terkandung pada prinsipprinsip utama menerangkan hubungan wartawan dengan masyarakat sekitar yang membezakan peranan wartawan di Malaysia dengan wartawan di negara lain (Chamil, 2011). Wartawan Malaysia mendukung prinsip Rukun Negara dan berperanan menyokong proses pembinaan negara, memupuk keharmonian antara kaum dan perpaduan nasional 
serta mewujudkan masyarakat yang liberal, toleran dan demokratik. Ini bersesuaian dengan latar belakang politik dan sosial negara Malaysia yang terdiri dari masyarakat yang berbilang kaum, agama dan budaya. Keharmonian serta penyatuan antara kaum di Malaysia perlu dibina dan dikekalkan bagi menyokong pembinaan sebuah negara maju yang manfaatnya dapat dinikmati semua pihak.

Kemunculan etika kewartawanan Malaysia (EKM) yang dipanggil sebagai Tatasusila Kewartawanan Malaysia pada 1989 dianggap sebagai satu langkah awal menaiktarafkan profesion kewartawanan melalui pembentukan satu garis panduan standard dalam kerjaya. Kod etika yang dibentuk oleh Institut Akhbar Malaysia (Malaysian Press Institute-MPI) dan Persatuan Editor Akhbar (Organization for Newspapers Editors-ONE) bukan dokumen undang-undang dan tidak mengikat wartawan untuk menuruti perkara yang dikemukakan. Ia lebih bersifat sukarela. Etika mengandungi ciri-ciri murni yang harus diamalkan dengan rasa tanggungjawab dan jujur pada diri. Pada kod etika terkandung tugas serta tanggungjawab wartawan kepada rakyat dan negaranya. Selain itu, kod etika turut mewakili dan menerangkan persekitaran sosiobudaya, politik negara, agama serta kepercayaan masyarakat yang diwakili (Akoje \& Mohd Helmi, 2014).

Bagi mewujudkan kerjaya yang lebih profesional, etika berperanan penting sebagai komponen utama pada identiti profesional bagi bidang kewartawanan (Deuze, 2005; Craft, 2017). Kemunculan pesaing kepada wartawan dan perkembangan teknologi media digital menjadikan mereka perlu bergerak dengan lebih pantas dalam persekitaran proses kerja yang terbatas. Hal ini perlu diseimbangkan dengan kekuatan amalan etika dalam kalangan wartawan bagi membezakan antara wartawan amatur yang terdiri daripada wartawan warga, wartawan komuniti dan seumpamanya dengan wartawan profesional.

Terdapat piawaian serta keperluan khusus yang diberikan oleh para sarjana dalam mentakrif istilah "profesional". Bayles (1981) memberikan kriteria khusus bagi bidang pekerjaan yang profesional, iaitu adanya ilmu pengetahuan yang meliputi teori dan kemahiran tertentu; latihan intensif yang berterusan; memberikan khidmat untuk masyarakat agar terus bergerak dengan lancar; mempunyai badan profesional yang bertanggungjawab menentukan standard; kod etika yang memandu dan mengawal ahlinya; pensijilan yang dikeluarkan oleh badan profesional; autonomi dalam membuat keputusan.

Turk (2006) berpendapat bahawa sesuatu pekerjaan boleh menjadi profesional dengan adanya syarat-syarat, iaitu mempunyai badan pengetahuan yang berasaskan penyelidikan; sistem pendidikan standard yang mencipta dan menyebarkan pengetahuan; pembelajaran profesional sepanjang hayat; prinsip etika teras; dan rasa tanggungjawab untuk memperbaiki masyarakat awam. Hal yang hampir sama dikemukakan oleh beberapa orang sarjana lain seperti perlunya badan pengetahuan profesional, kesedaran sosial, kod etika, lesen untuk mempraktik dan bertanggungjawab (Nash, 2013; Hirst, 2010; Bacon, 1999; Drewry dalam A.F. Yassin, 1986; Grunig \& Hunt, 1984). Selain itu terdapat juga beberapa ciri-ciri khusus profesional yang dikatakan perlu ada dalam diri setiap wartawan iaitu bersifat objektif, mempunyai autonomi dalam kerjaya, berkhidmat untuk masyarakat, pantas dan cepat, serta mempunyai etika yang tinggi (Golding \& Elliott, 1979; Merritt, 1995; Kovach \& Rosenstiel, 2001; Deuze, 2005). Walaupun terdapat banyak sarjana memberikan pandangan berkaitan ciri-ciri yang membentuk tipologi dalam mentakrif "profesional", wujud beberapa kesamaan dan keperluan etika adalah antara ciri utama yang perlu ada. 
A. Kadir Jasin (2013) dalam penulisannya menyatakan etika kewartawanan kini diancam oleh pengguna media baharu yang tidak memahami semangat yang terkandung dalam etika yang menjadi pegangan pengamal media arus perdana. Wartawan warga tidak memahami etika dan dengan kemunculan medium baru seperti media sosial telah mengakibatkan dunia pemberitaan menjadi semakin terbuka luas sehinggakan isu-isu etika, keadilan dan kesamaan menjadi suatu yang asing.

Etika lebih sukar untuk dihormati dan dipraktikkan oleh kewartawanan dalam talian (Phillips, 2010) ditambah dengan adanya isu-isu berkaitan kawalan kewangan dan 'ratings' yang menjadi hal utama dalam industri pemberitaan. Sungguhpun begitu, kajian yang dilakukan oleh Jamilah Hamzah et al (2020) menunjukkan etika dalam penulisan berita masih lagi diperlukan walaupun berdepan dengan persaingan daripada wartawan warga yang dikatakan tidak berpegang pada perkara tersebut. Kod etika yang khusus untuk wartawansama ada pengamal media tradisional mahupun yang baru-diperlukan bagi menjamin kualiti pemberitaan yang sampai kepada khalayak adalah yang memenuhi prinsip-prinsip berita dan disampaikan dengan penuh tanggungjawab.

Kod etika merupakan instrumen yang penting dalam memantau kualiti maklumat dan sebagai jaminan bahawa wartawan menjalankan tanggungjawabnya secara profesional (Mauri Rios, Marcos-Garcia, \& Zuberogoitia-Espilla, 2020). Bagi Zin Mahmud (BH Online, 17 Oktober 2019), wartawan profesional perlu dibezakan dengan wartawan warga melalui penaiktarafan dan pengukuhan ciri-ciri profesionalisme pada kerjaya. Penekanan pada penggunaan kod etika juga diperlukan bagi meletakkan wartawan dan kerjayanya pada satu tahap yang positif, terutama pada mata masyarakat.

Sistem media di Malaysia akan lebih positif sekiranya segala isu berbangkit dalam dunia kewartawanan dapat diseimbangkan dengan ketinggian tahap etika dalam kalangan wartawan. Profesion ini juga akan lebih dipandang tinggi dan dihormati oleh masyarakat sekiranya wujud satu garis panduan kerjaya yang jelas dalam kalangan pengamalnya. Segalanya perlu bermula dari dalam diri wartawan itu sendiri. Apakah wartawan tahu dan mempraktikkan etika kewartawanan dalam kerjayanya? Apakah kepentingan etika dalam kerjaya mereka? Apakah etika berhubungan dengan profesionalisme kewartawanan? Semua soalan ini perlu dijawab terlebih dahulu oleh para wartawan untuk mereka membina jati diri dan semangat untuk mengharungi cabaran kerjaya sebagai wartawan pada era digital.

\section{Wartawan, Akta dan Etika}

Keeble (1994) menyatakan wartawan bekerja di bawah banyak tekanan dan sekatan, antaranya daripada pemerintah, pengiklan, undang-undang dan sebagainya. Satu cara untuk para wartawan menjalankan tugas secara profesional adalah dengan mengikuti kod etika yang ada. Sememangnya kerjaya kewartawanan tidak hanya sekadar melapor, menganalisis atau menyiasat sesuatu untuk menghasilkan berita tetapi turut memerlukan pengamalnya menepati etika dan tanggungjawab dalam profesion tersebut dan seterusnya memberikan makna yang positif pada kerjaya kewartawanan itu sendiri.

Suasana kewartawanan dan pemberitaan di Malaysia turut menampakkan wujudnya perlanggaran akta oleh wartawan serta wujudnya aduan oleh masyarakat yang meragui profesion ini sehingga memberikan reputasi yang kurang baik (Nor Adzrah, Suria Hani \& Fauziah, 2012). Suara-suara yang meragui kredibiliti wartawan di Malaysia sudah lama 
kedengaran, apatah lagi apabila dikaitkan dengan berita-berita politik negara dengan anggapan setiap surat khabar adalah penyebar berita kerajaan (BH Online, 16 Oktober 2019). Majoriti akhbar arus perdana di Malaysia berlatarbelakangkan parti politik dan kerana itulah akhbar dilabel berat sebelah dan hanya menjaga sesetengah pihak. Hal ini menyebabkan masyarakat mempersoalkan peranan wartawan yang ada. Menurut Nur Jazlan (The Malaysian Insider, 29 Disember 2013),

\begin{abstract}
Akhbar arus perdana dilihat seakan "hilang taring" kerana selain edaran yang merosot dengan alasan terpaksa bersaing dengan media digital yang majoritinya percuma, kandungan akhbar-akhbar ini, juga sudah mula dipersoalkan rakyat. Majoriti rakyat mula melabelkan bahawa akhbar arus perdana ini, tidak lagi berjuang untuk rakyat sebaliknya lebih menjadi kepada "suara" sesetengah pihak yang berkepentingan sehingga mengabaikan tuntutan untuk memperjuangkan hak rakyat.
\end{abstract}

Etika sememangnya berkait rapat dalam profesionalisme sesebuah kerjaya. Oleh itu, bagi memastikan warga media melaksanakan tugas secara profesional, satu mekanisme yang berbentuk panduan bagi tujuan pengamalan harus diwujudkan. Etika merupakan garis panduan yang ideal untuk membawa para petugas dalam sesuatu bidang melaksanakan tugas dan tanggungjawab dengan penuh berhemah. Aspek yang penting pada etika adalah penghayatan, bukan paksaan. Etika mengandungi ciri-ciri murni yang harus diamalkan secara jujur oleh setiap individu dalam sesuatu profesion. Etika bukan undang-undang, tetapi satu bentuk kawalan diri atau peraturan diri. Oleh itu, para wartawan dituntut untuk menerima dan memahami etika yang dibentuk. Kajian yang dijalankan oleh Yassin (1986) dan Mus Chairil dan Chin (1990) berkaitan kesedaran mengenai etika kewartawanan menunjukkan wartawan pada ketika itu menyedari keperluan etika kepada kerjaya. Walaupun EKM diperkenalkan pada 1989, kajian awal mendapati sebahagian besar wartawan sudah sedia tahu tentang etika secara umum dan keperluannya kepada kerjaya kewartawanan. Pandangan wartawan tentang EKM perlu diteliti semula memandangkan pembentukannya sudah lebih daripada 30 tahun. Liesbeth Hermans dan Nico Drok (2018) menyatakan bahawa pentakrifan semula beberapa perkara dalam dunia kewartawanan adalah penting kerana konteks sosial kewartawanan telah berubah pada abad ini akibat perkembangan teknologi, budaya sosial dan juga pembangunan ekonomi yang memberikan kesan yang besar kepada dunia penyediaan maklumat dan berita. Nilai-nilai kewartawanan profesional perlu diperhatikan semula untuk disesuaikan dengan bentuk kewartawanan yang berorientasi kepada masyarakat dan negara.

Memetik kata Chamil (2011, hlm. 15), “Etika Kewartawanan Malaysia telah disusun oleh wartawan untuk wartawan. Oleh yang demikian kaum wartawan Malaysia bertanggung jawab untuk menghayati dan mematuhinya". Namun, bagi Goodwin (1987), bukan mudah untuk membuat semua wartawan menghayati etika dan tidak semua berminat kepada persoalan teori dan etika. Ditambah pula apabila tiada penguatkuasaan kepada pematuhan EKM dikenakan dan pengetahuan mengenai EKM tidak disampaikan secara meluas serta tidak juga dibincangkan secara mendalam (Faridah, 2015). Selain itu, wartawan juga tidak diwajibkan untuk mengetahui serta mengingati EKM (Mus Chairil, 2000). Sifat etika yang tidak mutlak dan subjektif kerana dipengaruhi oleh banyak faktor dalam kehidupan dan persekitaran pengamalnya mendorong kepada sikap acuh tak acuh para wartawan terhadap EKM. 
Hal ini membimbangkan kerana wartawan perlu sentiasa memberikan penekanan kepada etika yang merupakan satu bentuk garis panduan tingkah laku bagi mengelak berlakunya perlanggaran moral atau tindakan melampaui batas dalam tugasannya. Ini bertepatan dengan kenyataan Jones (1980) bahawa etika dibentuk untuk melindungi pengguna, pengamal media, pemilik organisasi media dan individu yang dipertanggungjawabkan dengan apa sahaja yang dicetak atau disiarkan.

Sudah 32 tahun EKM diperkenalkan kepada para wartawan dan seharusnya ia sudah mantap bukan sahaja kepada diri wartawan tetapi juga kepada profesionalisme kerjaya kewartawanan. Namun, sebaliknya yang berlaku apabila aspek amalan dan penguatkuasaan terhadap etika dalam kalangan wartawan masih longgar. Ditambah dengan pengetahuan mengenainya juga tidak menyeluruh sehingga MPI mengambil inisiatif mengedarkannya semula kepada organisasi media di Malaysia (Utusan Online, Mei 2011) selain turut berhadapan dengan masalah kepelbagaian interpretasi kod etika di kalangan individu wartawan itu sendiri (A. Samad Ismail, 1995). Oleh itu, penting untuk mengetahui pemikiran wartawan terhadap kod etika ini sebagaimana disebut oleh Faridah Ibrahim et al. (2000) bahawa yang dipentingkan bukan lagi untuk mewujudkan kod etika tetapi lebih kepada mengetahui sikap dan pemikiran pengamal media itu sendiri terhadap kod etika yang ada. Ini kerana, kesedaran tentang kepentingan etika kewartawanan dalam kerjaya dapat membantu diri para wartawan untuk bertindak lebih profesional. Oleh itu, kajian ini dilakukan untuk mendapatkan jawapan sejauh mana wartawan akhbar mengetahui dan menggunakan EKM selain kepentingan dan perkaitannya dengan ciri-ciri profesional pada kerjaya wartawan.

\section{KAEDAH KAJIAN}

Kajian ini menganalisis sebanyak 272 borang soal selidik yang diedarkan secara rawak mudah kepada wartawan yang bekerja di lima akhbar berbahasa Melayu di Malaysia, iaitu Berita Harian, Harian Metro, Sinar Harian, Utusan Malaysia dan Kosmo! (sebelum diambil alih oleh syarikat Media Mulia Sdn Bhd). Pemilihan wartawan akhbar berbahasa Melayu bertepatan dengan situasi semasa yang berlaku dalam dunia persuratkhabaran negara apabila akhbar berbahasa Melayu mengalami peratusan kejatuhan pengedaran yang terbesar berbanding akhbar berbahasa lain. Menerusi data yang dikongsi oleh Audit Bureau of Circulation Malaysia 2018 (Goh, The Edge Malaysia, 18 September 2019) menunjukkan akhbar berbahasa Melayu mengalami peratusan kejatuhan pengedaran yang terbesar. iaitu sebanyak $55 \%$ dari 2 juta pada tahun 2013 kepada 905,000 pada tahun 2018. Akhbar berbahasa Cina mengalami kejatuhan kedua terbesar iaitu sebanyak 48\% dan diikuti oleh akhbar berbahasa Inggeris sebanyak $36 \%$.

Kajian ini membahagikan soal selidik kepada lima bahagian, iaitu latar belakang responden, pengetahuan tentang EKM 1989, kepentingan etika kewartawanan kepada kerjaya, pematuhan kepada prinsip etika dan ciri-ciri profesionalisme pada kerjaya wartawan. Data daripada borang soal selidik yang diedarkan di lima akhbar berbahasa Melayu terpilih, dianalisis menggunakan perisian Statistical Package for Social Sciences 25 dan analisis statistik deskriptif digunakan dengan mengeluarkan dapatan dalam bentuk peratus, min serta sisihan piawai. Hasil kajian dikemukakan dalam bentuk jadual yang diikuti dengan penerangan dan perbincangan. 


\section{DAPATAN KAJIAN DAN PERBINCANGAN}

Hasil kajian dibincangkan dengan membahagikan subtajuk berdasarkan pembahagian soal selidik iaitu latar belakang responden, pengetahuan kod etika kewartawanan oleh wartawan, kepentingan etika dalam kerjaya wartawan serta tahap etika wartawan kajian dan etika sebagai ciri profesionalisme wartawan.

\section{Latar Belakang Responden Kajian}

Jadual 1: Taburan Responden mengikut Jantina, Umur, Pendidikan, Pengalaman Kerja, dan Pendapatan

\begin{tabular}{|c|c|c|}
\hline Profil Responden & Kekerapan & Peratus (\%) \\
\hline $\begin{array}{l}\text { Jantina: } \\
\text { Lelaki } \\
\text { Perempuan }\end{array}$ & $\begin{array}{l}120 \\
152\end{array}$ & $\begin{array}{l}44.1 \\
55.9\end{array}$ \\
\hline $\begin{array}{l}\text { Umur: } \\
\qquad \begin{array}{l}\text { di bawah } 24 \text { tahun } \\
25-34 \\
35-44 \\
45-55\end{array}\end{array}$ & $\begin{array}{c}18 \\
182 \\
62 \\
10\end{array}$ & $\begin{array}{c}6.6 \\
66.9 \\
22.8 \\
3.7\end{array}$ \\
\hline $\begin{array}{l}\text { Pendidikan: } \\
\text { SPM/STPM } \\
\text { Sijil } \\
\text { Diploma } \\
\text { Ijazah } \\
\text { Sarjana/PHD }\end{array}$ & $\begin{array}{c}14 \\
3 \\
90 \\
157 \\
8\end{array}$ & $\begin{array}{c}5.1 \\
1.1 \\
33.1 \\
57.7 \\
2.9\end{array}$ \\
\hline $\begin{array}{l}\text { Pengalaman menjadi wartawan: } \\
\text { Kurang daripada } 1 \text { tahun } \\
1 \text { hingga } 4 \text { tahun } \\
5 \text { hingga } 10 \text { tahun } \\
11 \text { hingga } 14 \text { tahun } \\
15 \text { tahun ke atas }\end{array}$ & $\begin{array}{c}9 \\
105 \\
112 \\
25 \\
21\end{array}$ & $\begin{array}{c}3.3 \\
38.6 \\
41.2 \\
9.2 \\
7.7\end{array}$ \\
\hline $\begin{array}{l}\text { Pendapatan bulanan: } \\
\text { RM2,500 ke bawah } \\
\text { RM2,600-RM3,500 } \\
\text { RM3,600-RM4,000 } \\
\text { RM4,600-RM5,500 } \\
\text { RM5,600 ke atas }\end{array}$ & $\begin{array}{c}60 \\
141 \\
43 \\
22 \\
6\end{array}$ & $\begin{array}{c}22.1 \\
51.8 \\
15.8 \\
8.1 \\
2.2\end{array}$ \\
\hline $\begin{array}{l}\text { Bertukar organisasi media: } \\
\text { Tidak pernah } \\
\text { Satu } \\
\text { Dua } \\
\text { Tiga }\end{array}$ & $\begin{array}{c}182 \\
46 \\
27 \\
17\end{array}$ & $\begin{array}{c}66.9 \\
16.9 \\
9.9 \\
6.3\end{array}$ \\
\hline
\end{tabular}




\section{Pengetahuan tentang EKM}

\section{Jadual 2: Taburan Responden Mengikut Pengetahuan tentang Etika Kewartawanan 1989}

\section{Profil Responden}

Ahli badan/pertubuhan/persatuan Wartawan Malaysia:

Ya

Tidak
Kekerapan Peratus (\%)

193

79

71

29

205

75.4

$67 \quad 24.6$

Tidak

Faham dan jelas peruntukan EKM 1989:

Ya

197
8

Tidak

Tidak perlu menjawab

72.4

2.9

24.6

EKM 1989 menjadi pegangan dan amalan:
Ya

Tidak

Tidak perlu menjawab

197

8

67

193

12

67

Tidak perlu menjawab

EKM bantu membuat keputusan dalam kerjaya:

Ya

71

4.4

Tambah baik EKM:

Ya

87

32

Tidak

118

43.4

Tidak perlu menjawab

67

24.6

$\mathrm{N}=272$

Berdasarkan Jadual 2 di atas, jelas menunjukkan terdapat perkembangan terhadap pengetahuan wartawan mengenai EKM berbanding kajian lepas. Walaupun peratusan data bagi soalan-soalan berkaitan pengetahuan tentang EKM menunjukkan pada tahap yang sederhana iaitu antara $71 \%$ hingga $75.4 \%$, ini cukup memberikan gambaran bahawa kebanyakan wartawan akhbar berbahasa Melayu mengetahui dan memahami EKM. Sebanyak $75.4 \%$ atau 205 wartawan daripada 272 yang dikaji mengetahui kewujudan EKM dan dari jumlah tersebut, seramai 197 (72.4\%) wartawan mengakui faham dan jelas dengan peruntukan yang ada pada EKM serta bersetuju bahawa EKM telah menjadi pegangan dan amalan mereka. Selain itu, dapatan kajian juga menunjukkan seramai 193 (71\%) wartawan mengakui bahawa EKM membantu mereka membuat keputusan dalam kerjaya. Situasi ini menampakkan perubahan yang positif kepada profesion kewartawanan berbanding 
apa yang diperoleh dari kajian lepas, iaitu para editor berpendapat pengetahuan tentang kod etika tidak begitu meluas dan kesedaran umum mengenainya masih cetek dan kurang memuaskan (Faridah, Choong \& Ler, 2000; Faridah \& Lim, 1997; Mus Chairil \& Chin, 1991; Syed Arabi, 1986)

Berdasarkan dapatan yang diperoleh, kebanyakan wartawan dalam kajian ini menggunakan EKM sebagai satu instrumen kawalan diri dan garis panduan dalam kerjaya. Pengetahuan kepada etika yang ada akan memberikan kesan yang positif kepada dunia pemberitaan dan kewartawanan negara kerana EKM dibentuk bersesuaian untuk mewakili amalan kerja yang baik bersesuaian dengan sistem dan budaya negara Malaysia. Memetik kata-kata Tan Sri Mazlan Nordin (2011),

EKM bertujuan meningkatkan mutu akhbar-akhbar dan media elektronik daripada persaingan oleh mereka yang menggunakan cara tidak bertatasusila seperti yang berlaku di sesetengah negara maju. Ia juga bertujuan melindungi wartawan daripada dakwaan atau tuduhan yang tidak tepat, tidak adil, atau prejudis oleh pihak-pihak lain. (hlm. ix)

\section{Kepentingannya Etika dalam Kerjaya}

Berdasarkan keputusan kajian, kebanyakan wartawan akhbar berbahasa Melayu mengakui bahawa mereka melaksanakan tugas berlandaskan kod etika. Seramai 85.3\% (232) daripada 272 orang wartawan yang ditanya menyatakan bahawa mereka menggunakan kod etika dalam kerjaya mereka walaupun hanya sebanyak 75.4\% (205 orang) wartawan mengetahui tentang EKM. Walaupun ada antara wartawan yang dikaji tidak mengetahui EKM, mereka nyata mempunyai kefahaman etika yang tersendiri yang mungkin dibentuk daripada organisasi media yang diwakili seperti yang dinyatakan oleh Ahmad Murad Merican dalam Utusan.com.my bertarikh 29 Jun 2007, “bidang kewartawanan di Negara ini yang bermula sejak tahun 1806 tidak mempunyai kod etika seragam dan setiap syarikat memilih garis panduan sendiri". Faridah dan Rajib (1988) menyatakan bahawa setiap etika dalam apa-apa sahaja profesion, sebenarnya wujud dalam fikiran setiap individu yang bertanggungjawab kerana etika sememangnya berasaskan falsafah kebenaran dan kejujuran.

Berdasarkan pemerhatian yang dijalankan, wartawan yang tidak mengetahui EKM tidak bermaksud mereka tidak berpegang pada etika kerja yang baik. Walaupun terdapat wartawan yang tidak tahu atau mengguna pakai EKM, mereka berpegang pada pemahaman sendiri dalam memberi takrifan etika kerana ia bukanlah bersifat mutlak. Sebagaimana yang dinyatakan oleh Faridah Ibrahim "Etika boleh ditakrifkan sebagai satu garis panduan moral dalam kehidupan manusia mengenai apa yang betul dan apa yang salah" (Mohd Safar \& Zulkiple, 2015). Selain itu, EKM bukanlah satu sistem rigid yang wajib diaplikasikan kerana tiada sebarang garis tindakan yang dikenakan terhadap mana-mana wartawan yang melanggar perkara atau peruntukan kod etika ini (Mus Chairil Samani, 2000).

Hampir setengah jumlah wartawan kajian bersetuju bahawa kod etika yang ada telah membataskan kemampuan mereka membuat keputusan dan bertindak secara bebas dalam kerjaya. Seramai 113 (41.5\%) daripada jumlah wartawan yang dikaji mengakui perkara ini namun wartawan tetap bersetuju bahawa etika adalah penting kepada tugasan dan 
kerjaya mereka. Majoriti wartawan yang dikaji iaitu seramai 256 (94.1\%) bersetuju bahawa wartawan perlu menghayati dan mematuhi etika kewartawanan. Hal ni jelas menunjukkan kepentingan etika dalam membantu wartawan melaksanakan tugas dan tanggungjawabnya kepada masyarakat dan negara.

\section{Jadual 3: Pandangan tentang Kepentingan Etika Kewartawanan kepada Kerjaya}

\begin{tabular}{lcc}
\multicolumn{1}{c}{ Profil Responden } & Kekerapan & $\begin{array}{c}\text { Peratus } \\
(\mathbf{\%})\end{array}$ \\
Mengguna pakai mana-mana etika kewartawanan & 232 & 85.3 \\
Ya & 15 & 5.5 \\
Tidak & 25 & 9.2 \\
Tidak pasti & & \\
Keperluan untuk wartawan menghayati dan mematuhi etika & & \\
kewartawanan & 256 & 94.1 \\
Ya & 11 & 4 \\
Tidak & 5 & 1.8 \\
Tidak pasti & & \\
Etika Kewartawanan mempengaruhi buat keputusan dalam kerjaya & 225 & 82.7 \\
Ya & 40 & 14.7 \\
Tidak & 7 & 2.6 \\
Tidak pasti & & \\
Etika kewartawanan sebagai panduan buat keputusan dalam kerjaya & 228 & 83.8 \\
Ya & 38 & 14 \\
Tidak & 6 & 2.2 \\
Tidak pasti & & \\
Etika Kewartawanan membataskan kemampuan untuk membuat & & \\
keputusan dan bertindak secara bebas & & \\
Ya & 113 & 41.5 \\
Tidak & 124 & 45.6 \\
Tidak pasti & 35 & 12.9 \\
\hline N-272 & &
\end{tabular}

$\mathrm{N}=272$

Kebanyakan wartawan kajian mengakui bahawa etika berpengaruh dalam membuat keputusan sewaktu bertugas. Seramai 225 (82.7\%) berpendapat situasi tersebut berlaku dan hal yang positif juga dilihat apabila seramai 228 (83.8\%) mengakui etika berperanan sebagai satu rangka dalam membuat keputusan semasa melaksanakan tugasannya. Dengan adanya kod etika, wartawan akan lebih terarah kerana perkara-perkara yang dinyatakan dapat membantu wartawan mengenal pasti masalah dan memberikan kesedaran kepada para wartawan tentang tugas dan peranan yang harus dijalankan. Selain itu, pengetahuan terhadap etika akan menyedarkan wartawan untuk sentiasa berwaspada terhadap tekanan yang memungkinkan hilangnya kebebasan pada media (Black, 1998). Sebuah negara yang bebas dan bermanusiawi akan terbentuk sekiranya wartawan menjadikan etika sebagai satu mekanisme formal dalam praktis kerjayanya (Louis \& Fieser, 2012). 


\section{Pematuhan Prinsip EKM dan Tahap Etika Wartawan Kajian}

Jadual 5: Taburan Wartawan Mengikut Pematuhan kepada Prinsip Etika

\begin{tabular}{|c|c|c|c|c|c|c|c|c|c|}
\hline \multirow[t]{2}{*}{ Penyataan/ Prinsip } & \multicolumn{5}{|c|}{ Skala } & \multirow[b]{2}{*}{ Jum } & \multirow[b]{2}{*}{ Min } & \multirow[b]{2}{*}{ SP } & \multirow[b]{2}{*}{ Tahap } \\
\hline & 1 & 2 & 3 & 4 & 5 & & & & \\
\hline $\begin{array}{l}\text {...melaporkan kebenaran } \\
\text { kerana masyarakat perlu } \\
\text { diberikan maklumat yang } \\
\text { benar. }\end{array}$ & 0 & 0 & $\begin{array}{l}0.7 \\
(2)\end{array}$ & $\begin{array}{c}48.5 \\
(132)\end{array}$ & $\begin{array}{c}50.7 \\
(138)\end{array}$ & $\begin{array}{c}99.2 \\
(270)\end{array}$ & 4.50 & .515 & $\begin{array}{l}\text { Sangat } \\
\text { Tinggi }\end{array}$ \\
\hline $\begin{array}{l}\text {...bebas memungut dan } \\
\text { menyiarkan berita secara } \\
\text { jujur bersesuaian dengan } \\
\text { prinsip dan semangat } \\
\text { Rukun Negara. }\end{array}$ & 0 & $\begin{array}{l}0.4 \\
(1)\end{array}$ & $\begin{array}{l}1.8 \\
(32)\end{array}$ & $\begin{array}{c}50.7 \\
(138)\end{array}$ & $\begin{array}{c}37.1 \\
(101)\end{array}$ & $\begin{array}{c}87.8 \\
(239)\end{array}$ & 4.25 & .667 & $\begin{array}{l}\text { Sangat } \\
\text { Tinggi }\end{array}$ \\
\hline $\begin{array}{l}\text {...bebas untuk membuat } \\
\text { ulasan dan memberikan } \\
\text { kritikan yang membina } \\
\text { dan saksama berlandaskan } \\
\text { prinsip dan semangat } \\
\text { Rukun Negara }\end{array}$ & 0 & $\begin{array}{l}1.8 \\
(5)\end{array}$ & $\begin{array}{l}14.3 \\
(39)\end{array}$ & $\begin{array}{c}50.7 \\
(138)\end{array}$ & $\begin{array}{l}33.1 \\
(90)\end{array}$ & $\begin{array}{c}83.8 \\
(228)\end{array}$ & 4.15 & .726 & Tinggi \\
\hline $\begin{array}{l}\text {...boleh menggunakan } \\
\text { pelbagai cara untuk } \\
\text { mendapatkan berita tetapi } \\
\text { perlu dengan cara yang } \\
\text { wajar dan memikirkan } \\
\text { kepentingan orang ramai. }\end{array}$ & 0 & 0 & $\begin{array}{l}1.8 \\
(5)\end{array}$ & $\begin{array}{c}58.8 \\
(160)\end{array}$ & $\begin{array}{c}39.3 \\
(107)\end{array}$ & $\begin{array}{c}98.1 \\
(267)\end{array}$ & 4.38 & .522 & $\begin{array}{l}\text { Sangat } \\
\text { Tinggi }\end{array}$ \\
\hline
\end{tabular}

\begin{tabular}{llllllllll}
\hline $\begin{array}{l}\text {...bertanggungjawab untuk } \\
\text { membetulkan kesilapan } \\
\text { dalam laporan dengan }\end{array}$ & 0 & 0 & 2.6 & 51.1 & 46.3 & 97.4 & 4.44 & .547 & Sangat \\
segera. & & & $(7)$ & $(139)$ & $(126)$ & $(265)$ & & & Tinggi \\
\end{tabular}

\begin{tabular}{|c|c|c|c|c|c|c|c|c|c|}
\hline $\begin{array}{l}\text {...menghormati kerahsiaan } \\
\text { sumber berita. }\end{array}$ & 0 & 0 & $\begin{array}{l}0.4 \\
(1)\end{array}$ & $\begin{array}{l}47.4 \\
(129)\end{array}$ & $\begin{array}{r}52.2 \\
(142)\end{array}$ & $\begin{array}{l}99.6 \\
(271)\end{array}$ & 4.52 & .508 & $\begin{array}{l}\text { Sangat } \\
\text { Tinggi }\end{array}$ \\
\hline $\begin{array}{l}\text {...menjaga kesopanan dan } \\
\text { tertib dalam perlakuan } \\
\text { ketika bertugas. }\end{array}$ & 0 & 0 & 0 & $\begin{array}{c}50.0 \\
(136)\end{array}$ & $\begin{array}{c}50.0 \\
(136)\end{array}$ & $\begin{array}{c}100 \\
(272)\end{array}$ & 4.50 & .501 & $\begin{array}{l}\text { Sangat } \\
\text { Tinggi }\end{array}$ \\
\hline $\begin{array}{l}\text {...mengelak daripada } \\
\text { melakukan plagiat, fitnah } \\
\text { dan menghasut serta } \\
\text { menolak sebarang bentuk } \\
\text { rasuah. }\end{array}$ & 0 & 0 & $\begin{array}{l}1.8 \\
(5)\end{array}$ & $\begin{array}{c}48.5 \\
(132)\end{array}$ & $\begin{array}{l}49.6 \\
(135)\end{array}$ & $\begin{array}{c}98.1 \\
(267)\end{array}$ & 4.48 & .536 & $\begin{array}{l}\text { Sangat } \\
\text { Tinggi }\end{array}$ \\
\hline $\begin{array}{l}\text {...mengelak daripada } \\
\text { melaporkan sesuatu } \\
\text { yang bersifat perkauman, } \\
\text { melampau atau } \\
\text { bertentangan dengan } \\
\text { tatasusila masyarakat } \\
\text { majmuk Malaysia. }\end{array}$ & $\begin{array}{l}0.4 \\
(1)\end{array}$ & 0 & $\begin{array}{l}1.5 \\
(4)\end{array}$ & $\begin{array}{c}47.8 \\
(130)\end{array}$ & $\begin{array}{c}50.4 \\
(137)\end{array}$ & $\begin{array}{c}98.2 \\
(267)\end{array}$ & 4.48 & .569 & $\begin{array}{l}\text { Sangat } \\
\text { Tinggi }\end{array}$ \\
\hline
\end{tabular}




\begin{tabular}{lccccccccc}
\hline ...memahami undang- & 0.4 & 0 & 1.8 & 53.5 & 44.5 & 98 & 4.42 & .570 & Sangat \\
$\begin{array}{l}\text { undang dan peraturan } \\
\begin{array}{l}\text { Negara yang berkait dengan } \\
\text { profesion kewartawanan. }\end{array}\end{array}$ & $(1)$ & & $(5)$ & $(145)$ & $(121)$ & $(266)$ & & & Tinggi \\
\hline
\end{tabular}

1 Sangat Tidak Setuju, 2 Tidak Setuju, 3 Kurang Setuju, 4 Setuju, 5 Sangat Setuju

Bagi mengukur tahap etika wartawan, 8 prinsip yang dinyatakan dalam EKM diuji dengan mengemukakan 10 soalan kepada para wartawan kajian. Persepsi wartawan kajian terhadap prinsip EKM seperti melaporkan kebenaran kerana masyarakat perlu diberikan maklumat yang benar, menghormati kerahsiaan sumber, mengelak daripada berlakunya plagiat, fitnah dan menghasut serta menolak sebarang bentuk rasuah dan sebagainya direkodkan. Data kajian dikutip dengan menggunakan soal selidik berskala 5 mata.

Jadual 5 menunjukkan kepatuhan wartawan terhadap prinsip-prinsip EKM. Kebanyakan wartawan kajian memilih sangat bersetuju dan setuju kepada perkara-perkara yang dinyatakan dan ini jelas menunjukkan pematuhan mereka kepada kod etika dan amalan kepada budaya kerja yang sihat dan positif. Dapat diperhatikan bahawa kesemua perkara pada EKM yang disebut di atas berada pada tahap sangat tinggi dipilih oleh wartawan dengan nilai min antara 4.25 hingga 4.50. Keadaan ini bersesuaian dengan yang disebut oleh Faridah dan Rajib (1988) bahawa etika terkandung nilai-nilai yang baik dan berasas daripada falsafah kebenaran dan kejujuran. Oleh itu, setiap ahli yang bertanggungjawab dalam sesebuah profesion berkemungkinan besar akan bertindak selari dengan etika yang ada.

Berdasarkan urutan pematuhan kepada EKM, perkara menjaga kesopanan dan tertib dalam perlakuan ketika bertugas menjadi pilihan yang utama iaitu 100\% (272) wartawan mengakui mengamalkannya. Ini diikuti perkara menghormati kerahsiaan sumber, 99.6\% (271) sebagai yang kedua, perkara melaporkan kebenaran 99.2\% (270) sebagai pilihan ketiga, perkara mengelak daripada melaporkan sesuatu yang bersifat perkauman, melampau atau bertentangan dengan tatasusila masyarakat majmuk Malaysia, 98.2\% (267) sebagai pilihan keempat, dan kelima ialah perkara mengelak daripada melakukan plagiat, fitnah dan menghasut serta menolak sebarang bentuk rasuah iaitu sebanyak 98.1\% (267). Berkongsi kedudukan yang sama ialah perkara boleh menggunakan pelbagai cara untuk mendapatkan berita tetapi perlu wajar dan memikirkan kepentingan orang ramai sebanyak $98.1 \%$ (267).

Item ketujuh ialah perkara memahami undang-undang dan peraturan negara yang berkait dengan profesion kewartawanan, iaitu sebanyak $98 \%$ (266), diikuti bertanggungjawab untuk membetulkan kesilapan dalam laporan dengan segera 97.4\% (265) sebagai pilihan kelapan tertinggi. Seterusnya, perkara bebas memungut dan menyiarkan berita secara jujur bersesuaian dengan prinsip dan semangat Rukun Negara sebagai pilihan kesembilan tertinggi iaitu sebanyak $87.8 \%$ (239) dan akhir sekali, perkara bebas untuk membuat ulasan dan memberikan kritikan yang membina serta saksama berlandaskan prinsip dan semangat Rukun Negara iaitu sebanyak 83.8\% (228).

Ini menunjukkan bahawa wartawan di Malaysia mengamalkan perkara-perkara yang tercatat para EKM. Sememangnya apa-apa yang terkandung pada EKM bukan hanya meliputi prinsip-prinsip asas sebuah etika yang mengandungi nilai murni seperti melaporkan kebenaran, adil dan saksama, menghormati sumber berita, mengelak daripada perbuatan menghasut, plagiat, memfitnah, tetapi juga kandungan EKM berakar dan mewakili sistem serta persekitaran sosiobudaya, agama dan politik negara Malaysia. Perkara pada EKM seperti 
menggunakan cara yang wajar untuk memperoleh berita, memahami undang-undang dan peraturan negara menghindari berita bersifat perkauman, dan melampau dicipta bersesuaian dengan persekitaran masyarakat majmuk di Malaysia dan inilah perkara atau ciri-ciri khusus yang membezakan EKM dengan kod etika di negara lain. Sememangnya kewartawanan di setiap negara adalah berbeza disebabkan perbezaan ideologi, kepentingan nasional, politik, dan sosiobudaya (McQuail, 2010; Deuze, 2002; Hamelink, 1983, Akoje \& Mohd Helmi, 2014) yang menjadikan wujud ciri-ciri khusus mewakili setiap negara. Etika yang diamalkan oleh wartawan bersesuaian dengan sistem dan peranan media di Malaysia yang menyokong usaha-usaha pembangunan negara dan memupuk keharmonian masyarakat berbilang kaum di Malaysia.

\section{Jadual 6: Tahap Etika Wartawan Kajian}

\begin{tabular}{lcc}
\multicolumn{1}{c}{ Tahap Etika } & Kekerapan & Peratus \\
Sangat tinggi etika & 163 & 59.9 \\
Tinggi etika & 109 & 40.1 \\
\hline
\end{tabular}

Data mengenai pematuhan kepada EKM oleh wartawan kajian dianalisis untuk mengukur tahap etika wartawan yang dikaji (rujuk Jadual 6). Pembolehubah tahap etika wartawan dibentuk dengan memberikan nilaian baru berdasarkan skala Likert 5 aras iaitu sangat tinggi etika, tinggi etika, etika sederhana, rendah etika dan sangat rendah etika. Berdasarkan soalan-soalan yang dikemukakan, dapatan menunjukkan bahawa wartawan sangat beretika dalam melaksanakan tugas. Seramai 163 (59.9\%) wartawan yang dikaji berada pada tahap sangat tinggi etika dan 109 (40.1\%) wartawan pula berada pada tahap tinggi etika. Dari dapatan yang diperoleh ini menunjukkan wartawan kajian mempunyai tanggungjawab serta melaksanakan tugas dengan berwibawa sebagaimana dinyatakan oleh Faridah dan Rajib (1988) bahawa wartawan yang bertanggungjawab pasti mengamalkan etika kewartawanan kerana etika berkait rapat dengan perbuatan yang baik dan perilaku ini tentunya wujud dalam fikiran manusia yang waras.

\section{Etika sebagai Ciri Profesionalisme Kerjaya}

Berdasarkan jadual di atas, didapati wartawan kajian meletakkan etika sebagai pilihan ketujuh tertinggi dalam pemilihan ciri-ciri profesionalisme kerjaya. Berdasarkan data yang diperoleh, didapati wartawan memilih kesedaran sosial sebagai ciri-ciri profesional terpenting iaitu sebanyak 91.5\% (249). Diikuti oleh keperluan mengadakan latihan formal dan khusus sebagai pilihan kedua tertinggi, iaitu sebanyak 82.4\% (224), kursus yang berterusan sebagai pilihan ketiga tertinggi dengan jumlah wartawan yang memilih ialah $81.6 \%$ (222). Seterusnya pilihan keempat ialah badan pengetahuan ikhtisas atau profesional 81.3 (221), pilihan kelima tertinggi jujur dan objektif iaitu sebanyak 79\% (215) yang telah memilih ciri-ciri ini dan yang keenam ialah bertanggungjawab memelihara nama baik kerjaya iaitu sebanyak $78.3 \%$ (213).

Kod etika kewartawanan berada pada pilihan ketujuh tertinggi iaitu sebanyak $77.9 \%$ (212), dan diikuti oleh autonomi dalam kerjaya iaitu sebanyak 77.6\% (211). Manakala ciriciri profesional seperti mempunyai semangat dan iltizam yang tinggi, lesen mempraktik kewartawanan dan mempunyai Ijazah Sarjana Muda berada pada pilihan tiga terendah oleh wartawan. 
Berdasarkan Jadual 7, dapat dirumuskan bahawa kod etika wartawan tetap menjadi pilihan sebagai antara ciri-ciri yang diperlukan untuk membentuk profesionalisme kerjaya wartawan. Sungguhnya berada pada pilihan ketujuh tertinggi, pemilihan oleh 212 orang wartawan daripada 272 jelas membuktikan bahawa wartawan kajian mengakui kepentingan kod etika kepada kerjaya.

\section{Jadual 7: Ciri-ciri Mencapai Profesionalisme Kerjaya}

\begin{tabular}{|c|c|c|}
\hline Elemen Profesionalisme & Kekerapan & Peratus \\
\hline Kesedaran sosial & 249 & 91.5 \\
\hline Latihan formal dan khusus & 224 & 82.4 \\
\hline Kursus yang berterusan & 222 & 81.6 \\
\hline Lesen mempraktik & 155 & 57 \\
\hline Mempunyai Ijazah Sarjana Muda & 89 & 32.7 \\
\hline Bertanggungjawab memelihara nama baik kerjaya & 213 & 78.3 \\
\hline Badan pengetahuan ikhtisas/ profesional & 221 & 81.3 \\
\hline Iltizam/bersemangat tinggi & 176 & 64.7 \\
\hline Kod etika kewartawanan & 212 & 77.9 \\
\hline Autonomi kerjaya & 211 & 77.6 \\
\hline Jujur dan objektif & 215 & 79 \\
\hline
\end{tabular}

$\mathrm{N}=272$

\section{KESIMPULAN}

Wartawan memerlukan asas dan landasan yang kukuh dalam mengendalikan urusan pemberitaan dan kerana itu satu garis panduan atau etika yang jelas serta menyeluruh perlu dibentuk. Ini semua bertujuan untuk memastikan wujud kawalan ke atas diri wartawan untuk terus beretika dalam kerjayanya dan dalam masa yang sama memberikan kebebasan kepada wartawan bekerja dengan betul dan jujur. Kajian ini telah membuktikan bahawa majoriti wartawan mengakui menggunakan kod etika sebagai garis panduan dalam kerjaya dan sebagai satu kerangka membataskan tindakan wartawan daripada melakukan sesuatu yang negatif dan tidak bertanggungjawab. Dari segi amalan terhadap prinsip yang ada pada EKM, wartawan mengamalkan kesemua perkara pada EKM dengan baik apabila lebih separuh daripada jumlah wartawan yang dikaji berada pada tahap sangat tinggi etikanya.

Kini, wartawan semakin menerima, faham dan mengakui kepentingan EKM kepada diri dan kerjaya. Walaupun terdapat segelintir yang tidak tahu atau tidak mengendahkan EKM, secara prinsip amalan etika, mereka tetap sealiran dengan perkara-perkara yang dikemukakan pada EKM. Ini kerana wartawan sudah sedia berada dalam ruang lingkup kerjaya yang berpaksikan etika sejagat. Pada prinsip kewartawanan sudah ada nilai baik serta benar dan EKM menyempurnakan prinsip dan nilai kewartawanan bersesuaian dengan konteks Malaysia. Majoriti wartawan dalam kajian ini bekerja berasaskan etika kewartawanan 
sama ada menjadikan EKM sebagai pegangan ataupun sekadar memegang erat prinsip etika sejagat yang memandu wartawan ke arah tindakan yang lebih profesional.

Wartawan yang profesional perlu berpegang pada etika bagi membezakan mereka daripada masyarakat umum yang turut melakukan aktiviti kewartawanan. Usaha ke arah meningkatkan tahap etika dan seterusnya menjadikan kerjaya wartawan diiktiraf sebagai profesional akan memberikan manfaat bukan hanya kepada para wartawan, malah menyebarluaskan pengaruh yang baik kepada masyarakat dan negara. Oleh itu, dunia kewartawanan di Malaysia perlu dikuasai oleh wartawan yang mempunyai tahap etika yang akan mempengaruhi profesional wartawan yang akhirnya mampu menaikkan kredibiliti kandungan pemberitaan dan mengembalikan kuasa akhbar "arus perdana" pada mata masyarakat.

\section{RUJUKAN}

A. Kadir Jasin. (2013, 18 Oktober). Etika kewartawanan terancam. Malaysian Press Institute. Diakses dari https://mpi.my/release/kadir-jasin-etika-kewartawanterancam

A. Samad Ismail (1995, Oktober 28-29). Etika kewartawanan dan penulisan: Pengalaman dan harapan. Seminar Kebangsaan Etika dalam Penulisan Kewartawanan. Kertas 7. Kuala Lumpur.

A.F. Yassin (1986). Etika dan wartawan: Satu kajian kes di Malaysia, Petaling Jaya: Fajar Bakti.

Akmar Hayati Ahmad Ghazali. (2008). Cabaran komunikasi massa kini. Selangor: Penerbit Univeriti Putra Malaysia.

Akoje, T. P. \& Mohd Helmi Abd Rahim, (2014). Development of journalism ethics: A comparative analysis of codes of ethics in Nigeria, United Kingdom, United States of America, India and Russia. Malaysian Journal of Communication. 30 (2), 221-238.

Bacon, W. (1999). What is a journalist in a university? Media International Australia, 90(1), 79-90. Bayles, M.D. (1981). Professional ethics. California: Wadsworth Publishing Co.

Black, J., Steele, B., \& Barney, R. (1999). Doing ethics in journalism: A handbook with case studies. ( $3^{\text {rd }}$ ed) . Boston: Allyn \& Bacon.

Chamil Wariya. (2011). Kod etika kewartawanan Malaysia. Petaling Jaya: Media Global Matrix Sdn Bhd.

Craft, S. (2017). Distinguishing features: reconsidering the link between journalism's professional status and ethics. Journalism and Communication Monographs. 19 (4), 260-301.

Day, L.A., (1991). Ethics in media communications: Cases and controversies, Belmont, California: Wadsmonth Publishing Company.

Deuze, M. (2005). Popular journalism and professional ideology: Tabloid reporters and editors speak out. Media Culture E Society, 27 (6), 861-882.

Deuze, M. (2005). What is journalism? Professional identity and ideology of journalists reconsidered. Journalism, 6(4), 442-464.

Faridah Ibrahim \& Mohd Rajib Ghani. (1988). Journalism ethics: An overview concept. Jurnal Komunikasi, 4, 28-36.

Faridah Ibrahim \& Mus Chairil Samani. (2000). Etika kewartawanan (Edisi Kedua). Subang Jaya: FAR Publisher. 
Faridah Ibrahim. (2015). Etika kewartawanan dan pengamalan dalam konteks Islam. Dlm. Mohd Safar Hasim \& Zulkiple Abd Ghani. Komunikasi dan media dari perspektif Islam: Konsep dan amalan (hlm. 160-175). Bangi: Penerbit Universiti Kebangsaan Malaysia.

Faridah Ibrahim. (2003). Falsafah dan etika kewartawanan di Malaysia: Antara tuntutan profesionalisme dan kepentingan industri. Jurnal Komunikasi. 19, 59-78.

Filak, V. F. (2019). Dynamics of news reporting and writing: Foundational skills for a digital age. California: Thousand Oaks, CQ Press.

Flanagin, A.J. \& Metzger, M.J. (2000). Perception of internet information credibility. Journalism $\mathcal{E}$ Mass Communication Quarterly, 77(3), 515-540.

Golding P. \& Elliott, P. (1979). Making the news. London: Longman.

Goodwin H. E,. (1987). Grouping for ethics in journalism. Ames: Iowa State University Press. Grunig, J.E. \& Hunt, T. (1984). Managing public relations. New York: Holt, Rinehart, Winston. Halimahton Shaari \& Ismail Sualman. (2009). Issues in media and communication. Shah Alam: Pusat Penerbitan Universiti, UITM.

Halimahton Shaari, (2004). Universal and parochial influences on journalistic ethics. Forum Komunikasi. 5 (1), 41-49.

Hamelink, C. (1983). Cultural autonomy in global communication. Norwood, NJ: Ablex.

Hermans L \& Drok, N. (2018). Placing constructive journalism in context. Journalism Practice. 12 (6), 679-694

Hirst, M. (2010). Journalism education "down under" A tale of two paradigms. Journalism Studies, 11 (1), 83-98.

Jamilah Hamzah, Khairunnisa Kamal Azi, Nurul Hidayah Hamid, Wan Mohd Noor Hafiz Wan Mansor \& Norsiah Abdul Hamid. (2020). Perubahan landskap teknologi media: kesan, cabaran dan masa depan dunia kewartawanan. International Journal of Modern Trends in Social Sciences, 3 (14). 184-195.

Jarvis, S.E., Stroud, N.E. \& Gilliland, A.A. (2009). College students, news use, and trust, Communication Research Reports. 26 (1), 30-39.

Jones, J.C. 1980. Mass media codes of ethics and councils: A comparative international study on professional standards. Paris: UNESCO.

Goh, J. (2019, 18 September). ABC's future hazy as major publishers plan to pull out. The Edge Malaysia. Diakses daripada https://www.theedgemarkets.com/article/ abcs-future-hazy-major-publishers-plan-pull-out

Keeble, R. (1994). The newspapers handbook. London: Routledge.

Kovach, B. \& Rosenstiel, T. (2001). Elements of journalism: what news people should know and the public should expect. New York: Three Rivers Press.

Louis P. P. \& Fieser, J. (2012). Ethics discovering right and wrong. Boston: Wadsworth.

McQuail, D. (1992). Media performance mass communication and the public interest. London: Sage Publication.

McQuail, D. (2005). Mass communication theory (ed. 5). Beverly Hills, CA: Sage Publications. McQuail, D. (2010). McQuail's mass communication theory (Ed. 6). London: Sage Publications. Merritt, D. (1995). Public journalism and public life. National Civic Review. 84 (3). 262-266

Meyers, C., Wyatt, W.N., Borden, S.L., \& Wasserman, E. (2012). Professionalism, not professionals. Journal of Mass Media Ethics, 27, 189-205. 
Mohd Safar H. (1996). Akhbar dan kuasa: Perkembangan sistem akhbar di Malaysia sejak 1806. Kuala Lumpur: Penerbit Universiti Malaya.

Mortensen, T. B. \& Keshelashvili, A. (2013). If everyone with a camera can do this, then what? Professional photojournalists' sense of professional threat in the face of citizen photojournalism. Visual Communication Quarterly. 20. 144-158.

Mus Chairil Samani \& Chin Ah Peng (2000). Etika kewartawanan: persoalan freebies di kalangan wartawan. Dlm. Faridah Ibrahim \& Mus Chairil Samani.(eds.) Etika kewartawanan (Edisi Kedua). Subang Jaya: F.A.R Publishers.

Mus Chairil Samani. (2000). Pemberita: Profesional atau Pekerjaan? Dlm. Faridah Ibrahim dan Mus Chairil Samani (eds.). Etika kewartawanan (Edisi kedua) Subang Jaya: F.A.R. Publishers.

Nash, C. (2013). Journalism as a research discipline. Pacific Journalism Review, 19(2), 123-135

Nor Adzrah Ramlee, Suria Hani A. Rahman \& Fauziah Hassan. (2012). Wartawan sebagai pendakwah dan pembangun ummah. Bangi: Universiti Kebangsaan Malaysia.

Nur Jazlan. (2013, 29 Disember). Cabaran dan realiti arus perdana di Malaysia. The Malaysian Insider.com. Diakses daripada http://www.themalaysianinsider.com/opinion/nur-jazlan/ article/cabaran-dan-realiti-media-arus-perdana-di-malaysia

Ogan, C.L. (1982). Development journalism/communication: The status of the concept. Gazette. 29:3-13.

Phillips, A. (2010). Transparency and the new ethics of journalism. Journalism Practice. 4(3), 373-382.

Schweiger, W. (2000). Media credibility-experience or image? A survey on the credibility of the world wide web in Germany in comparison to other media. European Journal of Communication, 15 (1), 37-59.

Shoemaker, P. \& Reese, S. (2004). Mediating the message in the 21st century. A media sociology perspective. New York: Routledge.

Sriramesh, Krishnamurthy. (2004). Public relations in Asia: An anthology. Singapore: Thomson Stovall, J.G. 2004. Web journalism: practice and promise of a new medium. Boston: Ally and Bacon.

Turk, J. V. (2006). The professional bond: Public relations education and the practice. Virginia: The Commission on Public Relations Education.

Utusan Online. (2011, 21 Mac). Majlis Media iktiraf wartawan kerjaya profesional. Diakses dari www.ww1.utusan.com.my/utusan/info.asp? $y=2011 \& \mathrm{dt}=0321 \&$ pub=Utusan_ Malaysia\&sec=Dalam_Negeri\&pg=dn_13.htm)

Utusan Online. (2013, 29 Jan). Kematangan Wartawan, Majlis Akhbar (http://utusan.com.my/ utusan/Rencana/20130129/re_06/Kematangan-wartawan-MajlisAkhbar\#ixzz34rho1ONf)

Utusan Online. (2011, Mei). Memahami Etika Kewartawanan (www.ww1.utusan.com.my/ utusan/info=asp? y=2011\&dt=0531\&pub=Utusan_Malaysia\&sec=Rencana\&pg=re_09.htm)

Waisbord, S. (2013). Reinventing professionalism: Journalism and news in global perspective. Cambridge, UK: Polity Press.

Wasserman, H. (2017). Fake news from Africa: Panics, politics and paradigms. Journalism 2020. 21 (1), 3-16.

Weaver, D., \& Löffelholz, M. (2008). Questioning national, cultural and disciplinary boundaries: A call for global journalism research. Dlm. Martin Löffelholz \& David Weaver (eds.) Global journalism research. theories, methods, findings, future (hlm. 3-12). Oxford: Blackwell. 
Wong, Kok Keong. 2004. Asian-based development journalism and political elections. Gazette: International Journal for Communication Studies, 6 (1), 25-40.

Zin Mahmud, (2019, 17 Oktober). Keperluan pertahankan kewartawanan Melayu. BH Online. Diakses dari https://www.bharian.com.my/kolumnis/2019/10/618630/keperluanpertahankan-kewartawanan-melayu 